\title{
Active mineral cycling in a Jamaican seagrass sediment
}

\author{
T. H. Blackburn ${ }^{1}$, D. B. Nedwell ${ }^{2}$, W. J. Wiebe ${ }^{3}$ \\ ${ }^{1}$ Department of Microbial Ecology, Institute of Biological Sciences, University of Aarhus, DK-8000 Aarhus C, Denmark \\ ${ }^{2}$ Department of Biology, University of Essex, Colchester CO4 3SQ, United Kingdom \\ ${ }^{3}$ Department of Microbiology, University of Georgia, 816 Biological Sciences Building, Athens, Georgia 30602, USA
}

\begin{abstract}
There was an active cycling of $\mathrm{C}$ and $\mathrm{N}$ in the sediments underlying a Halodule beaudetti meadow. Intensive $\mathrm{C}$ cycling was inferred from high rates of $\mathrm{O}_{2}$ uptake $\left(131 \mathrm{mmol} \mathrm{m} \mathrm{m}^{-2} \mathrm{~d}^{-1}\right), \mathrm{CO}_{2}$ production (199 mmol $\mathrm{m}^{-2} \mathrm{~d}^{-1}$ ) and sulfate reduction ( $34 \mathrm{mmol} \mathrm{m} \mathrm{m}^{-2} \mathrm{~d}^{-1}$ ). Subsurface input of organic matter was indicated by the high rates of sulfate reduction and the presence of a short-lived organic pool $(5$ to $10 \mathrm{~h})$. We suggest that this organic pool which was associated with whole plants, was due to root excretion. There was little accumulation of sulfide, which was probably oxidised in the deeper sediment strata by $\mathrm{O}_{2}$, secreted from roots. Nitrogen cycling was equally active. ${ }^{15} \mathrm{NH}_{4}{ }^{+}$dilution indicated a net production rate for $\mathrm{NH}_{4}^{+}$of ca $8 \mathrm{mmol} \mathrm{m}^{-2} \mathrm{~d}^{-1}$ within the sediment, available for root uptake. Ammonium also accumulated in the sediment overnight (ca $7 \mathrm{mmol} \mathrm{m}^{-2}$ ) and disappeared during the day, presumably due to greater uptake by the roots in light compared to dark. Rates of nitrogen fixation were low (ca $1 \mathrm{mmol} \mathrm{m} \mathrm{m}^{-2} \mathrm{~d}^{-1}$ ) and did not vary much during the day. Dawn denitrification rates were high (ca $4 \mathrm{mmol} \mathrm{m}^{-2} \mathrm{~d}^{-1}$ ), but they decreased during the day.
\end{abstract}

KEY WORDS: Seagrass $\cdot$ Root exudates - Sulphate reduction · Diurnal changes

\section{INTRODUCTION}

Little is known regarding the nutrient status of tropical and semi-tropical seagrasses, but it is probable that at least some are nitrogen-limited (Bulthuis et al. 1992, Fourqurean et al. 1992b) although some are phosphorus-limited (Short et al. 1990, Fourqurean et al. 1992a). Similarly, exceptions to $\mathrm{N}$ limitation in Zostera marina have been reported (Zimmerman et al. 1987, Pedersen \& Borum 1992). Nutrients, specifically nitrogen, are usually in low concentrations in oligotrophic semi-tropical waters associated with seagrass meadows (Boon 1986). Because of the occurrence of higher concentrations of $\mathrm{NH}_{4}{ }^{+}$in the sediments (Boon 1986), it is likely that tropical seagrasses obtain nitrogen from the sediment through their roots, rather than from water through their leaves. There is little experimental evidence from tropical waters to support this proposition, but there is ample evidence from temperate areas that root uptake of nitrogen by $Z$. marina roots is important (lizumi et al. 1982, Short \& McRoy 1984). In addition to living in a potentially nitrogen- limited environment, there are inevitable nitrogen losses from all seagrasses and meadows by exudation, export, animal predation and denitrification. These losses must be compensated by import of nitrogen to the seagrass ecosystem in the form of nitrogencontaining organic detritus, nitrogen assimilation from the water through the leaves or by nitrogen fixation in the rhizosphere or by epiphytes (Hemminga et al. 1991).

The first possibility is unlikely in nutrient-poor waters, unless the meadow is located near an estuary, which could also be a source of organic detritus. The sedimentation of detritus is, however, very dependent on water movement and on the type of plant meadow (Harlin et al. 1982). It has been recognised for many years that nitrogen fixation in the rhizosphere could be an important source of nitrogen to seagrasses (Patriquin \& Knowles 1972) and this activity may be related to root biomass in Thalassia testudinum (Capone \& Taylor 1980). The involvement of roots in nitrogen fixation may be due to the leakage of dissolved organic carbon from the root, which could act as 
a source of energy for anaerobic or aerobic nitrogen fixers in the sediment. There is much evidence for the transport of photosynthate from the leaves to the root in seagrasses (Oremland \& Taylor 1977, Wetzel \& Penhale 1979, Iizumi et al. 1980, Moriarty et al. 1986) and in other tropical ecosystems, root secretions by mangroves probably occurs (Blackburn et al. 1987. Nedwell et al. 1994, this issue). Large numbers of nitrogen-fixing bacteria occur in the rhizosphere of Zostera marina (Shieh et al. 1989), probably as a result of these secretions, and it is likely that seasonal and diurnal variations in rates of nitrogen fixation (Smith \& Hayasaka 1982) are due to these changes in photosynthesis and thus in the availability of dissolved organic carbon.

The purpose of this investigation was to examine the sediment underlying a Halodule beaudetti meadow to look for active carbon oxidation as evidence of dissolved organic leakage or secretion by the roots, and to see if this carbon metabolism could be linked to processes in the nitrogen cycle (mineralization, denitrification and nitrogen fixation). This was done in parallel with an investigation of mangrove sediments (Nedwell et al. 1994) and was initiated to confirm some earlier, preliminary observations (Blackburn et al. 1987).

\section{METHODS}

Study site. The site of the Halodule beaudetti (den Hartog) (Littler et al, 1989) bed was at Oyster Bay, Falmouth Harbour, Jamaica $\left(12^{\circ} 29^{\prime} \mathrm{N}, 77^{\circ} 38^{\prime} \mathrm{W}\right)$. The hydrology and biology of the Bay have been described (Taylor et al. 1966, Carpenter \& Selinger 1968, Seliger \& Fastie 1968). The site was at Stn 6 on the published map (Fig. 1 in Nedwell et al. 1994). The site was visited in August and December 1990.

Physical characteristics. Porosity and specific density of sediments were measured on $10 \mathrm{~cm}^{3}$ duplicate samples from each $2 \mathrm{~cm}$ depth interval to $8 \mathrm{~cm}$, after drying at $110^{\circ} \mathrm{C}$ for $12 \mathrm{~h}$.

Incubations. Shoots were removed from all sediment cores at the sediment-water interface. The activity of the cores at that time reflected the photosynthetic history of the whole plant, before shoot and core removal from the meadow. Oxygen and $\mathrm{\Sigma CO}_{2}$ fluxes were performed under a water phase, as were denitrificationnitrogen fixation incubations. Sulfate reduction and ${ }^{15} \mathrm{NH}_{4}^{+}$dilution incubations were without a water phase

Oxygen uptake by sediments. Triplicate sediment cores were taken in plexiglass tubes $18 \mathrm{~cm}$ i.d. $x$ ca $30 \mathrm{~cm}$ long), having first removed the plant shoots from a small area of the meadow. The cores were incubated in the laboratory, in the dark, at field tempera- ture $\left(29\right.$ to $\left.31^{\circ} \mathrm{C}\right)$. They were overlaid with water $\left(\begin{array}{ll}1 & 1\end{array}\right)$ from the station, which was aerated for 6 h to maintain the redox gradient across the sediment-water interface and to compensate for any disturbance caused by coring, prior to the flux incubations. The plexiglass tubes were closed and the removal of dissolved $\mathrm{O}_{2}$ in the stirred water was measured by a sensor (Model 1309, Strathkelvin Instruments, Ltd, Scotland). Care was taken to ensure that no air bubbles were trapped under the lid. The $\mathrm{O}_{2}$ concentration was not allowed to fall below $90 \%$ air saturation. The removal rate was calculated by linear regression, and the slopes were linear $(p<0.05)$ and were significantly different $(p<$ 0.05 ) from zero. The rates were corrected for $\mathrm{O}_{2}$ disappearance from water controls. Occasionally, the rate of $\mathrm{O}_{2}$ consumption was also measured by differences in $\mathrm{O}_{2}$ concentration by Winkler titration.

Sulfate reduction rates. Sulfate reduction rates were measured in triplicate in $2.5 \mathrm{~cm}$ i.d. cores, which contained silicone rubber-filled injection ports at $1 \mathrm{~cm}$ intervals. The sediment cores were injected at $2 \mathrm{~cm}$ intervals, down to $8 \mathrm{~cm}$, with ${ }^{35} \mathrm{SO}_{4}{ }^{2-}(2.5 \mu \mathrm{Ci}$ or $92.5 \mathrm{kBq}$; DuPont, Wilmington, DE, USA) in $25 \mu \mathrm{l}$ of anaerobic seawater. The cores were incubated in the dark at in situ temperature for $3 \mathrm{~h}$; they were then extruded and $2 \mathrm{~cm}$ sections were cut into $5 \mathrm{ml}$ zinc acetate $(5 \% \mathrm{w} / \mathrm{v})$ to stop biological activity and to preserve sulfide. The samples were processed to recover acid-volatile sulfides (AVS) and tin-reducible sulfides (TRS, which were pyrite and sulfur), in zinc traps (Skyring 1985). Subsamples were removed from the zinc acetate traps to measure ${ }^{35} \mathrm{~S}$, and the remainder of the trapped sulfide was measured by thiosulfate titration (American Public Health Association 1989). Pore water from $2 \mathrm{~cm}$ slices, which was obtained by centrifugation, was treated with $50 \mu$ of zinc acetate solution to precipitate sulfides. The sulfate concentration in the supernatant was measured by ion chromatography (Dionex Corp., Sunnyvale, CA, USA). Sulfate reduction rates were calculated (Sorokin 1962) and expressed as nmol $\mathrm{cm}^{-3} \mathrm{~d}^{-1}$ or integrated ( 0 to $8 \mathrm{~cm}$ ) as mmol $\mathrm{m}^{-2} \mathrm{~d}^{-1}$. In order to compare sulfate reduction rates with $\mathrm{CO}_{2}$ fluxes, rates were also expressed as meq. $C \mathrm{~m}^{-2} \mathrm{~d}^{-1}$, on the assumption that $1 \mathrm{SO}_{4}{ }^{2-}$ reduced was equivalent to $2 \mathrm{CO}_{2}$ produced.

Effect of incubation time on measured sulfate reduction. Multiple cores of sediment were taken at noon in December and were injected with ${ }^{35} \mathrm{SO}_{4}{ }^{2-}$. Duplicate cores were immediately extruded, cut into $2 \mathrm{~cm}$ sections and preserved in zinc acetate. The remaining cores were incubated at in situ temperature. Duplicate cores were sectioned and fixed at intervals up to $22 \mathrm{~h}$.

Net $\mathrm{CO}_{2}$ released from sediments. Two sediment cores tubes $(3.5 \mathrm{~cm}$ diameter $\times$ ca $7 \mathrm{~cm}$ long) were incu- 
bated with ca $7 \mathrm{ml}$ of overlying water at in situ temperature. The core was contained in a plexiglass tube $16 \mathrm{~cm}$ long, closed top and bottom with rubber stoppers. The top stopper was fitted with a magnet suspended from a nylon monofilament, rotated by an external revolving magnet (Blackburn 1987). The closed cores were incubated for $5 \mathrm{~h}$. The $\mathrm{\Sigma CO}_{2}$ was measured in $10 \mathrm{ml}$ replicate samples of the original water and of the overlying water after incubation (Talling 1973). The rate of change in $\Sigma \mathrm{CO}_{2} \mathrm{mmol} \mathrm{m}^{-2}$ $\mathrm{d}^{-1}$ was calculated.

Ammonium turnover in sediments. Ammonium turnover, production and consumption was measured by a ${ }^{15} \mathrm{NH}_{4}{ }^{+}$tracer method (Blackburn \& Henriksen 1983, Blackburn 1993). Sediment cores (20 cores $2.5 \mathrm{~cm}$ i.d. in plexiglass tubes with silicone rubber injection ports) were injected with ${ }^{15} \mathrm{NH}_{4}^{+}(200 \mu \mathrm{l}$ $0.01 \mathrm{M}, 99 \%{ }^{15} \mathrm{~N}$ ) at $2 \mathrm{~cm}$ intervals. All overlying water was removed from the sediment surface. The cores were incubated at in situ temperature. Half of the cores were processed at $1 \mathrm{~h}$ and the remainder at ca $10 \mathrm{~h}$ after injection. The cores were cut into $4 \mathrm{~cm}$ sections, which were shaken with $20 \mathrm{ml} 2 \mathrm{M} \mathrm{KCl}$ for $10 \mathrm{~min}$ at ambient temperature. The suspension was centrifuged at $3000 \times g$ for $10 \mathrm{~min}$. The $\mathrm{NH}_{4}{ }^{+}$and ${ }^{15} \mathrm{NH}_{4}{ }^{+}$concentrations were determined by colorimetric analysis (Solórzano 1969) and by mass spectrometry (Blackburn 1993), respectively. The total rate of $\mathrm{NH}_{4}{ }^{+}$production was calculated from the dilution of the ${ }^{15} \mathrm{NH}_{4}{ }^{+}$ label with time. The initial $1.0 \mathrm{~h}$ incubation allowed the added labelled $\mathrm{NH}_{4}{ }^{+}$to interact physically with the sediment.

Denitrification and nitrogen fixation rates. The principle of measuring denitrification and nitrogen fixation in the same soil sample, after treatment with acetylene (Yoshinari et al. 1977), was used in this experiment. Denitrification rates were measured by a method described for sediments (Andersen et al. 1984). The sediment (ca $7 \mathrm{~cm}$ in $3.5 \mathrm{~cm}$ i.d. plexiglass tubes with silicone rubber injection ports) was gently overlaid with ambient water (ca $7 \mathrm{~cm}$ ). The tubes were closed with rubber stoppers, and the top stopper was fitted with a magnetic stirrer, as in the $\mathrm{CO}_{2}$ flux measurements. Six sediment cores, with no headspace, were each injected with $100 \mu$ l of acetylenesaturated seawater at $0.5 \mathrm{~cm}$ intervals, and the overlying water was adjusted to $10 \%$ saturation with acetylene. Surplus water was allowed to escape through a hypodermic needle. Half of the cores were processed after ca $1 \mathrm{~h}$ and the rest after ca $3 \mathrm{~h}$. Processing consisted of removing $25 \mathrm{ml}$ of the overlying water to an evacuated $38 \mathrm{ml}$ serum bottle which was shaken vigorously. The remainder of the overlying water was discarded and the sediment transferred to a $250 \mathrm{ml}$ bottle containing $50 \mathrm{ml}$ seawater. The sedi- ment was shaken to form a suspension (10 min). Gas samples $(3 \mathrm{ml})$ were taken with a syringe from the serum bottle and the headspace of the sediment suspension to $3 \mathrm{ml}$ evacuated tubes (Venoject) for $\mathrm{N}_{2} \mathrm{O}$ and ethylene analysis by gas chromatography. The total net production rates of $\mathrm{N}_{2} \mathrm{O}$ and ethylene were calculated, using the appropriate Bunsen coefficients.

Diurnal variations in ammonium pools, denitrification, nitrogen fixation and sulfate reduction. In December 1990, at 07:00, 09:20, 12:30 and 14:00 h, cores were taken from the Halodule beaudetti meadow. Ammonium pools were measured at $2 \mathrm{~cm}$ intervals in duplicate cores. The cores were cut into $2 \mathrm{~cm}$ slices, which were extracted for $10 \mathrm{~min}$ in $10 \mathrm{ml}$ $2 \mathrm{M} \mathrm{KCl}$ before being centrifuged. The total $\mathrm{NH}_{4}{ }^{+}$pool was measured in the $\mathrm{KCl}$ extract and the concentrations per $\mathrm{cm}^{3}$ sediment were calculated using the porosity values. Denitrification, nitrogen fixation and sulfate reduction were measured as described.

\section{RESULTS}

There were marked differences among the rates of $\mathrm{O}_{2}$ uptake, $\mathrm{CO}_{2}$ production and $\mathrm{SO}_{4}{ }^{2-}$ reduction measured in August and December 1990 (Fig. 1). There was much lower activity in December and the largest difference was in the rates of $\mathrm{O}_{2}$ uptake. The summed rates of $\mathrm{O}_{2}$ uptake plus $\mathrm{SO}_{4}{ }^{2-}$ reduction equalled the rate of $\mathrm{CO}_{2}$ production for both August and December samples. The summed rates were 198 and 54 meq. $\mathrm{m}^{-2}$ $\mathrm{d}^{-1}$, compared with the $\mathrm{CO}_{2}$ production rates of 199 and 45 meq. $\mathrm{m}^{-2} \mathrm{~d}^{-1}$, respectively, for August and December. This implies that little $\mathrm{O}_{2}$ was available via the sediment-water interface for the oxidation of $\mathrm{NH}_{4}{ }^{+}$ $\mathrm{SH}^{-}$or other reduced compound in the sediment.

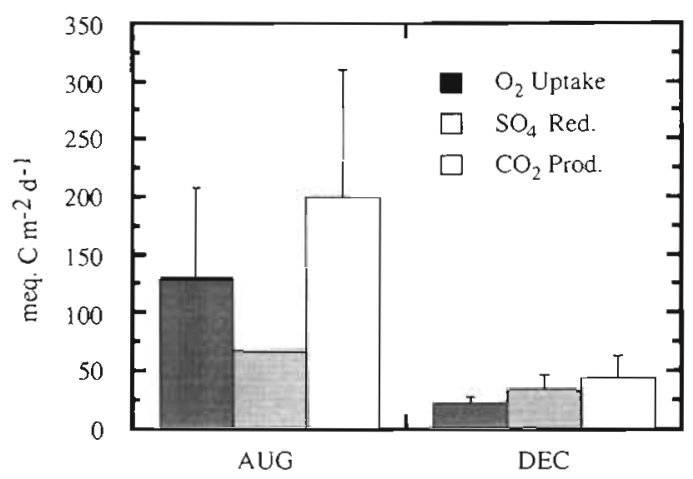

Fig. 1 Integrated $(0$ to $8 \mathrm{~cm})$ rates of oxygen uptake, sulfate reduction and $\Sigma \mathrm{CO}_{2}$ production as measured in August and December 1990. The rates are in meq. $\mathrm{m}^{-2} \mathrm{~d}^{-1}+\mathrm{SE}$ $(n=5)$ 


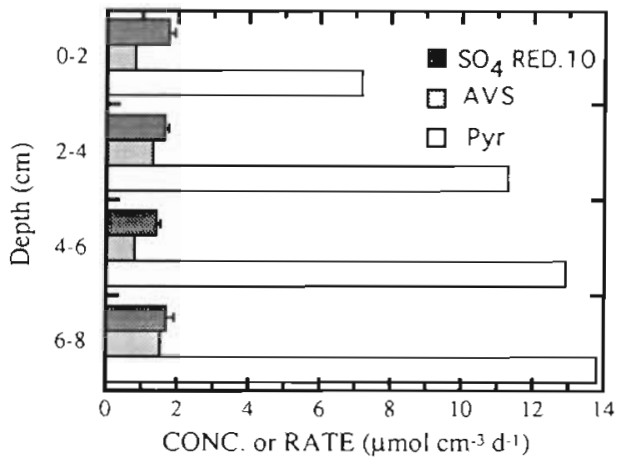

Fig. 2. Rates $(+\mathrm{SE})$ of sulfate reduction multiplied by 10 , and pools sizes of acid volatile sulfide (AVS) and pyrite (pyr)

There was evidence, however, that $\mathrm{SH}^{-}$did not accumulate in the sediment. The integrated $(0$ to $8 \mathrm{~cm}$ ) AVS pool was $88 \mathrm{mmol} \mathrm{m}^{-2}$ and the rate of sulfate reduction $(\mathrm{n}=6)$ was $16.3 \mathrm{mmol} \mathrm{m}^{-2} \mathrm{~d}^{-1}$, giving a turnover time of $5.4 \mathrm{~d}$. The turnover time for the TRS pool was $55 \mathrm{~d}$. As the $\mathrm{O}_{2}$ which reoxidised the sulfide could not have come via the sediment-water interface, it is possible that it was supplied from the plant roots. It should be noted that sulfate reducing activity was distributed quite evenly down to $8 \mathrm{~cm}$ depth, but AVS was lowest at 4 to $6 \mathrm{~cm}$, suggesting that it was removed from this stratum.

High rates of sulfate reduction occurred throughout the sediment (Fig. 2), which indicated an input of degradable organic matter into the deeper sediment layers. There was evidence that this organic matter was largely composed of a labile pool, which disappeared after the sediment core had been removed from the meadow and from the site of photosynthesis (Fig. 3). The data points are scattered, but no further net sulfate reduction occurred after 5 to $10 \mathrm{~h}$ incubation, giving these limits for the turnover of the organic pool.

The rates of sulfate reduction were almost equal in cores removed from the meadow during the day up to

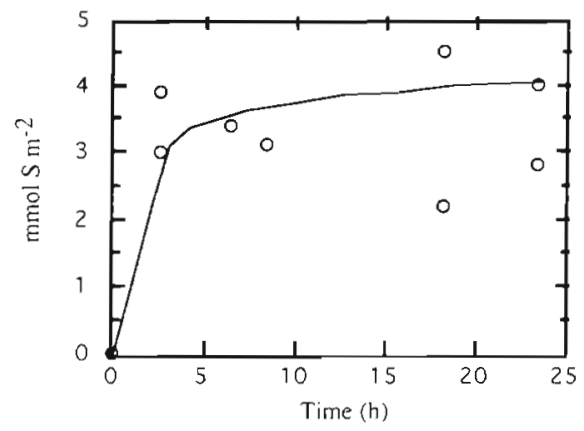

Fig. 3. Accumulation of reduced sulfur with time of incubation

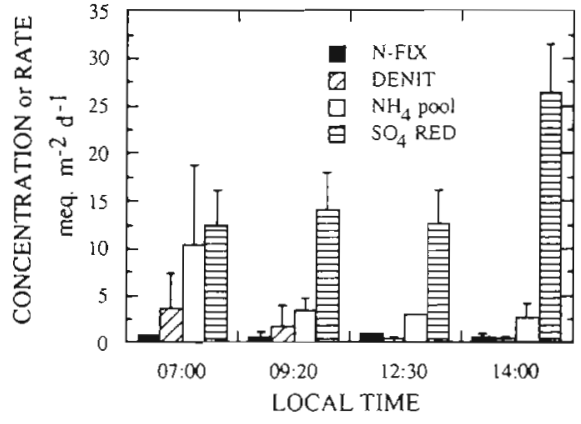

Fig. 4. Integrated $(0$ to $8 \mathrm{~cm})$ rates $(+\mathrm{SE})$ of nitrogen fixation, denitrification, sulfate reduction and pool size of $\mathrm{NH}_{4}{ }^{+}$at different times of sampling during a day in December

noon. In the afternoon, there was an increase in activity (Fig. 4). Ammonium pools had an opposite trend, with a high in the dawn sample (ca $10 \mathrm{mmol} \mathrm{m}^{-2}$ ) and decreasing during the day to ca $3 \mathrm{mmol} \mathrm{m}^{-2}$. Rates of nitrogen fixation were low (ca $1 \mathrm{mmol} \mathrm{m}^{-2} \mathrm{~d}^{-1}$ ) and did not change during the day. Denitnification rates started high (ca $4 \mathrm{mmol} \mathrm{m}^{-2} \mathrm{~d}^{-1}$ ) and decreased to ca $2 \mathrm{mmol}$ $\mathrm{m}^{-2} \mathrm{~d}^{-1}$. The $\mathrm{NH}_{4}{ }^{+}$pools were high in the dawn sample in all strata except the 0 to $2 \mathrm{~cm}$ layer, and all layers showed a decrease during the day (Fig. 5).

The main evidence for the active nature of nitrogen cycling in the rhizosphere of the Halodule beaudetti meadow is given by the ${ }^{15} \mathrm{NH}_{4}{ }^{+}$dilution data (Table 1). The sediment was very heterogeneous and the standard errors were high; the $\mathrm{NH}_{4}{ }^{+}$concentration at $0.15 \mathrm{~d}$ was $173 \pm 24 \mathrm{nmol} \mathrm{cm}^{-3}$ and $259 \pm 270$ at $0.71 \mathrm{~d}$. It is doubtful that any change in $\mathrm{NH}_{4}{ }^{+}$occurred between these 2 times, and for that reason, the rate of ${ }^{15} \mathrm{NH}_{4}{ }^{+}$dilution was calculated from a simple firstorder rate constant. The most active $\mathrm{NH}_{4}{ }^{+}$turnover occurred in the 0 to $4 \mathrm{~cm}$ stratum $\left(11.0 \mathrm{mmol} \mathrm{m}^{-2} \mathrm{~d}^{-1}\right)$. compared to the 4 to $8 \mathrm{~cm}$ layer $\left(5.3 \mathrm{mmol} \mathrm{m} \mathrm{m}^{-2} \mathrm{~d}^{-1}\right)$.

The large amount of ${ }^{15} \mathrm{NH}_{4}{ }^{+}$added, $200 \mathrm{nmol} \mathrm{cm}{ }^{-3}$ gave ca $90 \%$ enrichment. This high percentage had

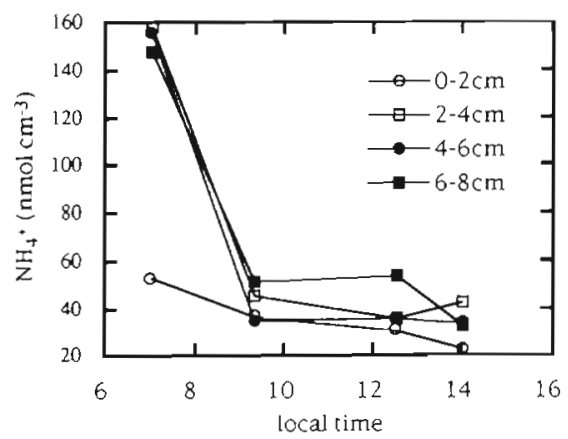

Fig. 5. Pool size of ammonium at different depths and at different times during the day 
Table 1. Ammonium production rates in sediment. Subscript values for $t$ are incubation time in days. Standard errors are given in parentheses

\begin{tabular}{|c|c|c|}
\hline & \multicolumn{2}{|c|}{ Depth $(\mathrm{cm})$} \\
\hline & $0-4$ & $4-8$ \\
\hline \multicolumn{3}{|c|}{$\mathrm{NH}_{4}{ }^{+}$conc. $\left(\mathrm{nmol} \mathrm{cm}{ }^{-3}\right)$ at: } \\
\hline$t_{015}$ & $173(24)$ & $195(139)$ \\
\hline$t_{0.7}$ & $259(270)$ & $156(50)$ \\
\hline \multicolumn{3}{|l|}{$\%{ }^{15} \mathrm{~N}$ at: } \\
\hline$t_{0.15}$ & $35.21(8.31)$ & $95.55(16.12)$ \\
\hline$t_{0.72}$ & $16.25(7.35)$ & $28.98(9.29)$ \\
\hline \multicolumn{3}{|l|}{$\%$ recovery ${ }^{15} \mathrm{~N}$ at: } \\
\hline$t_{0.15}$ & $55.63(14.30)$ & $67.12(8.62)$ \\
\hline$t_{0.71}$ & $25.06(5.48)$ & $41.87(8.17)$ \\
\hline$k\left(\mathrm{~d}^{-1}\right)$ & $1.40(0.51)$ & $0.81(0.48)$ \\
\hline $\begin{array}{l}\mathrm{NH}_{4}{ }^{+} \text {prod. rate } \\
\left(\mathrm{mmol} \mathrm{m}^{-2} \mathrm{~d}^{-1}\right)\end{array}$ & 11.03 & 5.32 \\
\hline $\begin{array}{l}\sum \mathrm{NH}_{4}{ }^{+} \text {prod. rate } \\
\left(\mathrm{mmol} \mathrm{m}^{-2} \mathrm{~d}^{-1}\right)\end{array}$ & \multicolumn{2}{|c|}{16.35} \\
\hline
\end{tabular}

decreased very significantly after a short incubation, which could only have occurred by the addition of ${ }^{14} \mathrm{NH}_{4}{ }^{+}$to the pool, not by uptake of ${ }^{15} \mathrm{NH}_{4}{ }^{+}$. It is assumed that the high initial excess of ${ }^{15} \mathrm{NH}_{4}{ }^{+}$did not affect the rate of organic nitrogen mineralization.

\section{DISCUSSION}

We can suggest no reason for the large differences in the rates of $\mathrm{O}_{2}$ uptake, $\mathrm{SO}_{4}{ }^{2-}$ reduction and $\Sigma \mathrm{CO}_{2}$ production as measured in August and December. It was interesting, however, that the equivalence between the rates of oxygen consumption and $\mathrm{CO}_{2}$ production indicated that there was no $\mathrm{O}_{2}$ available for $\mathrm{SH}^{-}$oxidation, or rather that there was no $\mathrm{O}_{2}$ available via a diffusive flux from the overlying water through the sediment surface. The rate of sulfate reduction was quite high throughout the sediment ( 0 to $8 \mathrm{~cm})$, yet there was no accumulation of AVS and a relatively rapid turnover of pyrite. The conclusion must be that $\mathrm{SH}^{-}$was reoxidised, and that this oxidation occurred at some depth in the sediment, again precluding a diffusive flux of $\mathrm{O}_{2}$ from the overlying water. If all the $\mathrm{SH}^{-}$were oxidised by a flux of $\mathrm{O}_{2}$ from the roots, this flux would have been equivalent to $33 \mathrm{mmol} \mathrm{m} \mathrm{m}^{-2} \mathrm{~d}^{-1}$, which is higher than the reported flow of $\mathrm{O}_{2}$ from roots of aquatic plants (Iizumi et al. 1980, Sand-Jensen \& Prahl 1982, Sand-Jensen et al. 1982, Thursby 1984). Similarly, only $18 \%$ of the $\mathrm{O}_{2}$ produced photosynthetically by Potamogeton perfoliatus L. was liberated from the roots in a double chamber (Kemp \& Murray 1986). There is, however, evidence for the oxidation of sulfide in the rhizosphere of rice seedlings (Joshi \& Hollis 1977). It is possible that the flow of $\mathrm{O}_{2}$ from roots may be higher in natural sediments, in the presence of $\mathrm{SH}^{-}$, which can stimulate the liberation of $\mathrm{O}_{2}$ (Penhale \& Wetzel 1983). We have suggested that a similar large flow of $\mathrm{O}_{2}$ occurs from the roots of mangrove trees (Nedwell et al. 1994).

In addition to the possible flow of $\mathrm{O}_{2}$ from the Halodule beaudetti roots, the present experiments provide evidence that the roots also contribute to a dissolved organic pool in the sediment, which is used by sulfatereducing bacteria. This pool was distributed throughout the sediment $(0$ to $8 \mathrm{~cm})$, it was labile $(5$ to $10 \mathrm{~h})$, and it consumed $3.5 \mathrm{mmol} \mathrm{SO}{ }^{2-} \mathrm{m}^{-2}$ in $\mathrm{ca} 7 \mathrm{~h}$. This would give a secretion rate of $24 \mathrm{mmol} \mathrm{C} \mathrm{m} \mathrm{m}^{-2} \mathrm{~d}^{-1}$. This rate was based on the rate of sulfate reduction in cores sampled at noon, but cores sampled at 14:00 h had higher activity and possibly cores sampled in the dark might have had much reduced activity.

We had expected to find high rates of nitrogen fixation associated with the oxidation of this labile carbon, but the rates were low (ca $1 \mathrm{mmol} \mathrm{m} \mathrm{m}^{-2} \mathrm{~d}^{-1}$ ), although similar to those previously reported (Capone \& Taylor 1980, Capone 1982, 1983a, b, Capone \& Carpenter 1982). Active nitrogen fixation seemed to be the most attractive explanation for the high rates of $\mathrm{NH}_{4}{ }^{+}$production in all the sediment layers, nitrogen fixing cells being hydrolysed to provide nitrogen to the plant. The alternative explanation would be the supply of nitrogen-rich detritus to the sediment from oligotrophic waters and the subsequent mixing of this material downward through the rhizosphere to 6 to $8 \mathrm{~cm}$ depth. Accumulation of $\mathrm{NH}_{4}{ }^{+}$at night suggested a minimum net production rate of $\mathrm{ca} 7 \mathrm{mmol} \mathrm{m}{ }^{-2}$ and ${ }^{15} \mathrm{NH}_{4}{ }^{+}$dilution gave a value of $16 \mathrm{mmol} \mathrm{m} \mathrm{m}^{-2} \mathrm{~d}^{-1}$ for total $\mathrm{NH}_{4}{ }^{+}$ production. If half this $\mathrm{NH}_{4}{ }^{+}$is used for bacterial cell synthesis, then ca $8 \mathrm{mmol} \mathrm{m}{ }^{-2} \mathrm{~d}^{-1}$ would have been available for plant uptake. In general, $\mathrm{NH}_{4}^{+}$production in the sediment exceeds the plant nitrogen demand (Iizumi et al. 1982, Short 1983, Dennison et al. 1987 , Caffrey \& Kemp 1990), but the situation may be different for tropical seagrasses and the $\mathrm{NH}_{4}{ }^{+}$concentrations in the sediment did not indicate that large diffusional losses were likely.

There is, thus, strong evidence for active nitrogen mineralization at depth in the sediment, and this nitrogen mineralization is associated with high rates of carbon oxidation by sulfate reduction. The carbon probably originates from the plant roots, but there is insufficient evidence to associate nitrogen fixation as being the source of the organic nitrogen which was mineralized. It is possible that the assay for nitrogen fixation was not performed under optimum conditions, even though the incubation times were short to prevent the consumption of labile carbon pools and changes in the redox status of the rhizosphere. The 
measured rates of nitrogen fixation were less than the rates of denitrification, and it is equally likely that denitrification was not determined optimally.

If all the proposed $\mathrm{NH}_{4}{ }^{+}$were assimilated by the plant into a biomass of $\mathrm{C}: \mathrm{N}=20$ (Halodule beaudetti roots had a $C: N$ of 23.4 ), then the carbon fixation rate

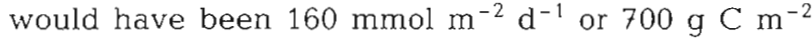
$\mathrm{yr}^{-1}$, which would be impressive for an unimpressive $H$. beaudetti meadow.

Acknowledgements. This work was supported by a grant to W.J.W. by USAID Program in Science and Technology Cooperation (PSTC): Diversity of Biological Resources; Atmospheric, Marine and Earth Sciences and by a NERC Small Research Grant (GR 9/246A) to D.N.B. We thank Dr Jeremy Woodley, Director of Discovery Bay Marine Laboratory, and the staff for their assistance.

\section{LITERATURE CITED}

American Public Health Association (1989). Standard methods for the examination of water and waste water, 17 th edn. APHA, Washington, DC

Andersen, T K., Jensen, M. H., Sørensen, J. (1984). Diurnal variation of nitrogen cycling in coastal, marine sediments. I. Denitrification. Mar. Biol. 83: 171-176

Blackburn, T. H. (1987). Nitrogen cycle in marine sediments. Ophelia 26: 65-76

Blackburn, T H. (1993). Turnover of ${ }^{15} \mathrm{NH}_{4}{ }^{+}$tracer in sediments. In: Kemp, P., Sherr, B. F., Sherr, E. B., Cole, J. J. (eds.) Current methods in aquatic microbial ecology. Lewis Publishers, New York, p. 643-648

Blackburn, T. H., Christensen, D., Fenger, A. M., Henriksen, K., Iizumi, H., Iversen, N., Limpsaichol, P. (1987). Mineralization processes in mangrove and seagrass sediments. Ao Yon - a mangrove in the Andaman Sea. Institute of Ecology and Genetics, University of Aarhus, Aarhus, p. 22-32

Blackburn, T H., Herriksen, K. (1983). Nitrogen cycling in different types of sediments from Danish waters. Limnol. Oceanogr. 28: 477-493

Boon, P. I. (1986). Nitrogen pools in seagrass beds of Cymodocea serrulata and Zostera capricorni of Moreton Bay, Australia. Aquat. Bot. 25: 1-19

Bulthuis, D. A., Axelrad, D. M., Mickelson, M. J. (1992). Growth of the seagrass Heterozostera tasmanica limited by nitrogen in Port Phillips Bay, Australia. Mar. Ecol. Prog Ser. 89: 269-275

Caffrey, J. M., Kemp, W. M. (1990). Nitrogen cyclıng in sediments with estuarine populations of Potamogeton perfoliatus and Zostera marina. Mar. Ecol. Prog. Ser. 66: $147-160$

Capone, D. G. (1982). Nitrogen fixation (acetylene reduction) by rhizosphere sediments of the eelgrass Zostera marina Mar. Ecol. Prog. Ser, 10:67-75

Capone, D. G. (1983a). Benthic nitrogen fixation. In: Carpenter, E. J., Capone, D. J. (eds.) Nitrogen in the marine environment. Academic Press, New York, p. 105-137

Capone, D. G. (1983b). $\mathrm{N}_{2}$ fixation in seagrass communities Mar. Technol. Soc. J. 17: 32-37

Capone, D. G., Carpenter, E. J. (1982). Nitrogen fixation in the marine environment. Science 217: 1140-1142

Capone, D. G., Taylor, B. F. (1980). $\mathrm{N}_{2}$ fixation in the rhizosphere of Thalassia testudinum. Can. J. Microbiol. 26 $998-1005$
Carpenter, J. H., Selinger, H. H. (1968). Studies at Oyster Bay, Jamaica, West Indies. II. Effects of flow patterns and exchange on bioluminescence distributions. J. mar. Res. 26: $256-271$

Dennison, W. C., Aller, R. C., Alberte, R. S. (1987). Sediment ammonium availability and eelgrass (Zostera marina) growth. Mar. Biol. 94: 469-477

Fourqurean, J. W., Zieman, J. C., Powell, G. V N. (1992a). Phosphorus limitation of primary production in Florida Bay: evidence from the C:N:P ratio of the dominant seagrass Thalassia testudinum. Limnol. Oceanogr. 37 $162-171$

Fourqurean, J. W., Zieman, J. C., Powell, G. V. N. (1992b). Relationships between porewater nutrients and seagrasses in a subtropical carbonate environment. Mar. Biol. 114: $57-63$

Harlin, M. M., Thorne-Miler, B., Boothroyd, J. C. (1982). Seagrass-sediment dynamics of a flood-tidal delta in Rhode Island (USA). Aquat. Bot. 127-138

Hemminga, M. A., Harrison, P. G., van Lent, F. (1991). The balance of nutrient losses and gains in seagrass meadows Mar. Ecol. Prog. Ser. 71: 85-96

Iizumi, H., Hattori, A., McRoy, C. P. (1980). Nitrate and nitrite in interstitial waters of eelgrass beds in relation to the rhizosphere. J. exp. mar. Biol. Ecol. 47: 191-201

Iizumi, H., Hattori, A., McRoy, C. P. (1982). Ammonium regeneration and assimilation in eelgrass (Zostera marina) beds. Mar. Biol. 66: 59-65

Joshi, M. M., Hollis, J. P. (1977). Interactions of Beggiatoa and rice plant: detoxification of hydrogen sulfide in the rice rhizosphere. Science 195: 179-180

Kemp, W. M., Murray, L. (1986). Oxygen release from roots of the submersed macrophyte Potamogeton perfoliatus L. regulating factors and ecological implications. Aquat. Bot. 26: $271-283$

Littler, D. S., Littler, M. M., Bucher, K. E., Norris, N. (1989). Marine plants of the Caribbean. Smithsonian Institution Press, Washington, DC

Moriarty, D. J. W., Iverson, R. L., Pollard, P. C. (1986). Exudation of organic carbon by the seagrass Halodule wrightii Aschers, and its effect on bacterial growth in the sediment. J. exp. mar. Biol. Ecol. 96: 115-126

Nedwell, D. B., Blackburn, T H., Wiebe, W. J. (1994). Dynamic nature of organic carbon, nitrogen and sulfur in sediment of a Jamaican mangrove forest. Mar. Ecol. Prog. Ser. 110: 223-231

Oremland, R. S., Taylor, B. F. (1977). Diurnal fluctuations of $\mathrm{O}_{2}, \mathrm{~N}_{2}$, and $\mathrm{CH}_{4}$ in the rhizosphere of Thalassia testudinum. Limnol. Oceanogr. 22: 566-570

Patriquin, D., Knowles, R. (1972). Nitrogen fixation in the rhizosphere of marine angiosperms. Mar. Biol. 16: 49-58

Pedersen, M F., Borum, J. (1992). Nitrogen dynamics of eelgrass Zostera marina during a late summer period of high growth and low nutrien availability. Mar. Ecol. Prog. Ser. 80: $65-73$

Penhale, P. A., Wetzel, R. G. (1983). Structural and functional adaptations of eelgrass (Zostera marina L.) to the anaerobic sediment environment. Can. J. Bot. 61. 1421-1428

Sand-Jensen, K., Prahl, C. (1982). Oxygen exchange with the lacunae and across leaves and roots of the submerged vascular macrophyte, Lobelia dortmanna L. New Phytol. 91. $103-120$

Sand-Jensen, K., Prahl, C., Stokholm, H. (1982). Oxygen release from roots of submerged aquatic macrophytes. Olkos 38: 349-354

Seliger, H. H., Fastie, W. G. (1968). Studies at Oyster Bay in Jamaica, West Indies. III. Measurements of underwater 
sunlight spectra. J. mar. Res. 26: 273-280

Shieh, W. Y., Simidu, U., Maruyama, Y (1989). Enumeration and characterization of nitrogen-fixing bacteria in an eelgrass (Zostera marina L.) bed. Microb. Ecol. 18: 249-259

Short, F. T (1983). The response of interstitial ammonium in eelgrass (Zostera marina $\mathrm{L}$.) beds to environmental perturbations. J. exp. mar. Biol. Ecol. 68: 195-208

Short, F. T., Dennison, W. C., Capone, D. G. (1990). Phosphorus-limited growth of the tropical seagrass Syringodium filiforme in carbonate sediments. Mar. Ecol. Prog. Ser. 62: $169-174$

Short, F. T., McRoy, C. P. (1984). Nitrogen uptake by leaves and roots of the seagrass Zostera marina $\mathrm{L}$. Botanica mar 27: $547-555$

Skyring, G. W. (1985). Anaerobic microbial processes in coral reef sediments. Proc. 5th int. coral Reef Congr. 3: 421-425

Smith, G. W., Hayasaka, S. S. (1982). Nitrogenase activity associated with Zostera marina from a North Carolina estuary. Can. J. Microbiol. 28: 448-451

Solórzano, L. (1969). Determination of ammonia in natural waters by the phenolhypochlorite method. Limnol. Oceanogr. 14: 799-801

Sorokin, Yu. I. (1962). Experimental investigation of bacterial sulfate resduction in the Black Sea. Microbiology 32:

This article was submitted to the editor
$320-335$

Talling, J. F. (1973). The application of some electrochemical methods to the measurement of photosynthesis and respiration in fresh waters. Freshwat. Biol. 3: 335-362

Taylor, W. R., Seliger, H. H., Fastie, W G., McElroy, W. D (1966). Biological and physical observations on a phosphorescent bay in Falmouth Harbour, Jamaica. W.I. J. mar Res. $24: 28-43$

Thursby, G. B. (1984). Root-exuded oxygen in the aquatic angiosperm Ruppia maritima. Mar. Ecol. Prog Ser 16: 303-305

Wetzel, R. G., Penhale, P. A. (1979). Transport of carbon and excretion of dissolved organic carbon by leaves and roots/rhizomes in seasgrasses and their epiphytes. Aquat. Bot. 6: $149-158$

Yoshinari, T., Hynes, R., Knowles, R. (1977). Acetylene inhibition of nitrous oxide reduction and measurement of denitrification and nitrogen fixation in soils. Soil Biol. Biochem. 9: $177-183$

Zimmerman, R. C., Smith, R. D., Alberte, R. S. (1987). Is growth of eelgrass nitrogen limited? A numerical simulation of the effects of light and nitrogen on the growth dynamics of Zostera marina. Mar. Ecol. Prog. Ser. 41: $167-176$

Manuscript first received: June 4, 1993

Revised version accepted: April 12, 1994 